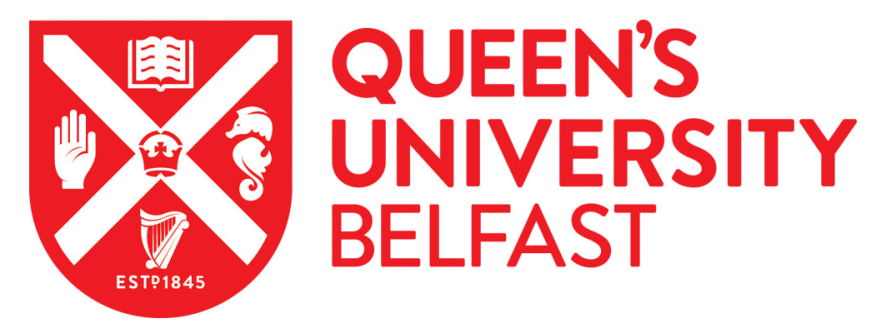

\title{
Acoustic absorption of hemp-lime construction
}

Kinnane, O., Reilly, A., Grimes, J., Pavia, S., \& Walker, R. (2016). Acoustic absorption of hemp-lime construction. Construction and Building Materials, 122, 674-682.

https://doi.org/10.1016/j.conbuildmat.2016.06.106

\section{Published in:}

Construction and Building Materials

\section{Document Version:}

Peer reviewed version

\section{Queen's University Belfast - Research Portal:}

Link to publication record in Queen's University Belfast Research Portal

\section{Publisher rights}

Copyright 2017 Elsevier

This manuscript is distributed under a Creative Commons Attribution-NonCommercial-NoDerivs License

(https://creativecommons.org/licenses/by-nc-nd/4.0/), which permits distribution and reproduction for non-commercial purposes, provided the author and source are cited.

\section{General rights}

Copyright for the publications made accessible via the Queen's University Belfast Research Portal is retained by the author(s) and / or other copyright owners and it is a condition of accessing these publications that users recognise and abide by the legal requirements associated with these rights.

\section{Take down policy}

The Research Portal is Queen's institutional repository that provides access to Queen's research output. Every effort has been made to ensure that content in the Research Portal does not infringe any person's rights, or applicable UK laws. If you discover content in the Research Portal that you believe breaches copyright or violates any law, please contact openaccess@qub.ac.uk. 


\section{Acoustic absorption of hemp-lime construction}

Authors: Oliver Kinnane1, Aidan Reilly¹, John Grimes², Sara Pavia² and Rosanne Walker²

Affiliations: (1) Department of Architecture, Queen's University, Belfast, Northern Ireland

(2) Department of Civil, Structural and Environmental Engineering, Trinity College Dublin, Ireland

Corresponding author: Aidan Reilly

E. o.kinnane@qub.ac.uk

T. $+44(0) 2890974520$

A. Dept. of Architecture, David Keir Building, Belfast BT9 5AG, Northern Ireland.

Prepared for: Construction and Building Materials

Prepared by: Kinnane et al.

15 June 2016 


\section{ABSTRACT}

2 Hemp-lime concrete is a sustainable alternative to standard wall construction

3 materials. It boasts excellent hygrothermal properties in part deriving from its

4 porous structure. This paper investigates the acoustic properties of hemp-lime

5 concrete, using binders developed from hydrated lime and pozzolans as well as

6 hydraulic and cementicious binders. To assess the acoustic absorption of hemp-lime

7 walls, as they are commonly finished in practical construction, wall sections are

8 rendered and the resulting impact on absorption is evaluated. Hemp-concretes with

9 lime-pozzolan binders display superior acoustic properties relative to more hydraulic

10 binders. These are diminished when rendered, as the open surface porosity is

11 affected, however hemp-lime construction offers the potential to meet standard and

12 guideline targets for spaces requiring acoustic treatment.

\section{KEYWORDS}

14 Acoustic sound absorption, hemp lime pozzolan concrete, porous materials,

15 sustainability 


\section{INTRODUCTION}

17 Contemporary building materials and constructions are expected to fulfil a range of

18 functions. As well as having structural integrity, they should insulate from heat loss,

19

20

22 weather and noise, manage moisture transport and ensure air tightness. Achieving these functions with materials of low environmental impact aids the effort to cut energy consumption associated with the construction of buildings. In contemporary constructions almost each functional requirement of the facade is fulfilled by a specific layer (e.g. rainscreen, insulation, air and vapour membranes) in the wall buildup. Bio-aggregate based materials offer possible solutions to many of these challenges, in a monolithic construction. An increasing number of performance characterisation studies focussed on bio-aggregate based materials (e.g straw, cork, flax, coconut) is enabling greater confidence in these materials as alternatives to standard construction materials, and more research is needed to ensure their wider usage [1][2].

Hemp based concrete is a bio-aggregate based construction material that enables low energy buildings both in construction and in use [3]. Hemp-based panels have already been investigated as sound-absorbing insulation panels [4], and the use of hemp concretes may offer advantageous acoustic performance compared to traditional concretes. Despite the dubiousness of some of the wilder claims about hemp (e.g. 'hemp crops require virtually no chemicals', [5]), hemp based concrete offers significant environmental advantages over traditional aggregates. Hemp's ability to sequester $\mathrm{CO}_{2}$ during its lifetime to more than offset the $\mathrm{CO}_{2}$ generated 
during manufacturing, transport and construction [6], makes it a particularly promising material in the efforts to reduce $\mathrm{CO}_{2}$ emissions and embodied energy associated with the development of building materials. Accurate and fair assessments of the embodied energy in any building product are difficult to make owing to the influence of various site and manufacturing route specific factors, such as the source of primary energy used in the production process and the transport distances involved. However, it is clear that hemp has a significant advantage over many traditional building materials due to the carbon sequestration that occurs during plant growth [7][8][9]. A commonly-cited estimate of the embodied energy in a hemp concrete wall is a study by Boutin et al [6]. A detailed study of the embodied energy involved in conventional concrete construction was carried out by Goggins et al [10]. Despite the caveats that apply to estimates of the embodied energy and greenhouse gas potential of construction materials, there appear to be significant environmental advantages to the use of hemp based products over traditional cement and hard aggregate concretes. There are also significant drawbacks to hemp as a construction material, notably its low strength and stiffness by comparison with traditional concrete. Its comparatively poor structural properties mean that the use of hemp as a main constituent of high rise and/or long span buildings is unlikely, but it offers many advantages when used in low rise domestic construction. A further key difference between hemp products and stone aggregate concretes is the hygroscopic nature of hemp; while this can have both positive and negative effects, it necessitates the use of alternative techniques and materials, which may present a 
60

challenge for widespread adoption - an example is the use of lime binders rather

61 than cement-based binders.

62 The use of a lime-pozzolan binder mix, in lieu of cement, increases the sustainability

63 further; pozzolans and materials with pozzolanic properties include metakaolin and

64 ground granulated blast furnace slag (GGBS) respectively. Lime ( $\mathrm{CaO}$ ) has a lower

65 firing temperature than cement [11] and hydrated lime (CL90: $\left.\mathrm{Ca}(\mathrm{OH})_{2}\right)$ absorbs $\mathrm{CO}_{2}$ when hardening through carbonation. Metakaolin $\left(\mathrm{Al}_{2} \mathrm{Si}_{2} \mathrm{O}_{7}\right)$ is a pozzolanic material, obtained by the calcination of kaolinitic clay, that can enhance the mechanical and durability properties of mortar and concrete [12]. Metakaolin is processed with less energy intensity than cement [13]. GGBS is a by-product of iron and steel manufacture and has long been used with Portland cement (PC) in concrete [14]. Although not a true pozzolan, its suitability as a binder constituent with lime is well established [15]. Hemp concrete with lime-pozzolan binders has demonstrated thermal [16], mechanical [17], durability [17] and moisture transport [18] qualities, and constructed hemp concrete buildings perform well [3][19].

A less emphasised role of walls, is the dissipation of noise produced in the spaces they envelop. Designing for acoustic performance is often an appendum to projects, achieved in post-occupancy by attaching noise absorbing panels to surfaces. Exposure to high levels of noise constitutes a risk to health and well-being [20], and has been related to a range of negative emotions [21][22] and cardiovascular disease [23]. The architectural tendency toward open-plan space, an increase in the specification of glass, smooth and polished hard surface finishes, has exacerbated the problem, with noise discomfort commonly reported in post-occupancy 
evaluations of buildings [24][25]. Designing for good acoustic performance is particularly pertinent in schools [26][27], where high background noise levels lead to reduced memory, attention span and motivation [28]. Construction methods and building materials that exhibit inherently good sound dissipation properties can offer solutions in environments where excess and reverberated noise is a nuisance such as classrooms [26][27].

Sound absorption coefficients $(\alpha)$ measured in the range 0 to 1 are commonly as low as $\alpha=0.04-0.08$ for smooth concrete or rendered wall surfaces [29]. A wide range of alternative concretes have been investigated for their acoustic performance, including porous [30] and aerated [31] concretes, and concretes containing crumb rubber [32] and vegetal materials [33] including hemp [34]. All these materials benefit from having a porous structure that enables sound absorption within the material's pores where the sound wave is dissipated via conversion to heat [35]. Hemp-lime composites are characterised by high porosity in the range of $70-80 \%$ [36]. Pores of different scales exist including macropores or inter-particle pores between the particles of hemp shiv, mesopores (intra-particle) within shiv and binder and micropores in the binder. Extensive research by the group of Gle, Gourdan and Arnaud has characterised the acoustic advantages, enabled by the porous nature of hemp composites through experimental [34] and modelling [37] investigations. Initially Cezero [38] investigated the impact of binder to shiv ratio showing a significant reduction in sound absorption with increasing binder content. Gle et al. [34][39] investigated the parameters of fabrication including density, particle size distribution, type of binder and water content on the acoustic properties 
of hemp concrete, with hydraulic and cementicious binders. In the low frequency range, up to $500 \mathrm{~Hz}$, hemp concretes were shown to exhibit sound absorption

108 coefficients of 0.2 to 0.5 depending on binder type, with the quick cement binder 109 displaying significantly lower sound absorption capabilities than hydraulic lime 110 binders [34]. Both loose hemp shiv, and hemp-lime concrete, contain pores of 111 multiple scales, varied descriptions of which are incorporated in developed models $112[34][37]$.

113 These acoustic studies have focused on the characterisation of loose hemp shiv or 114 the bulk hemp-lime concrete. However, hemp-lime concrete does not have the 115 necessary surface finish or durability of architectural walls and is often rendered 116 with a lime or lime-hemp binder [3]. These renders ensure the maintenance of the 117 moisture transport advantages of hemp-lime construction [11]. Hemp-lime renders 118 can retain relatively high porosity (52.9\% [8]); however, the skim finish results in the 119 closing of surface pores. A smooth or reflective finish significantly affects the sound 120 absorption characteristics of the construction material as exemplified by the wide 121 variance between fair-faced and painted concrete block [41]. With respect to hemp122 lime concrete, the addition of excess water during fabrication can result in a binder 123 layer forming close to the wall or sample moulding, resulting in a smooth and closed 124 surface that greatly reduces sound absorption [42].

125 This paper reports the sound absorption characteristics of rendered and unrendered 126 hemp concrete walls made with lime-pozzolan binders, and compares them with 127 hydraulic and cementitious binders. Hemp-lime construction is assessed with 
128 reference to acoustic design guidelines for spaces warranting of attentive acoustic 129 treatment.

\section{METHODS}

131 Acoustic absorption was tested on hemp lime wall sections in a laboratory with 132 minimal background noise. Details of the materials and testing procedure are 133 outlined below. The methodology developed by Grimes et. al. (2013) and validated 134 for the in situ measurement of the sound absorption characteristics of building 135 fabrics was used [41]. The procedure adapts ISO standards ISO 10534-2:2001 [43] 136 and ISO 13472-2:2010 [44] enabling in situ testing of constructed walls.

\section{$137 \quad 2.1$ MATERIALS}

\section{$138 \quad 2.1 .1$ HEMP}

139 Hemp varies with climate and harvest conditions amongst other factors [45]. The 140 hemp shiv used in this study is grown in Central France and supplied by La

141 Chanvrière de l'Aube and hence has a growth cycle consistent with those from other 142 hemp concrete acoustic evaluation studies [34]. Given the significance of particle 143 size on inter-pore structure [39] the particle size distribution is evaluated for a 144 sample of hemp used enabling confidence in comparison with these previous 145 studies. The particle size distribution for a sample of hemp is listed in Table 1 and the

146 three primary sizes shown in Figure 1 . The hemp shiv aggregate was mixed with six 147 different binders as described in Table 3. 
148 Hemp composite walls were cast in timber shuttering, in panels $1 \mathrm{~m}$ by $1 \mathrm{~m}$ and 300

$149 \mathrm{~mm}$ in thickness. The panels were allowed to cure outside for 1 year with protective

150 covering at $16^{\circ} \mathrm{C} \pm 4^{\circ} \mathrm{C}$ and relative humidity $50 \% \pm 15 \%$ as outlined in previous work

151 [16]. This was followed by 12 months at room temperature in the laboratory prior to

152 acoustic testing. Replicating common hemp concrete construction methods, the

153 walls were tamped in plywood shuttering by an experienced practitioner who

154 ensured consistent workability across all hemp-lime concretes. Methods and testing,

155 for example workability measurement tests, are as yet ill-defined for hemp-lime and

156 hence experience is relied upon as recommended by other authors [16][46].

157 Although the mechanical properties of hemp concretes have been shown to exhibit

158 variability, and to vary according to the dryness of the sample [47][48], this effect is

159 not seen for the acoustic properties: changes in sound absorption properties are not

160 significantly affected by moisture content [49]. Consequently, the hemp was allowed

161 to dry naturally; acoustic testing of the panels was undertaken 24 months after

162 casting when the natural drying process had reduced the material density to levels

163 documented in Table 3.

Table 1. Particle size distribution

\begin{tabular}{llll}
\hline $\begin{array}{l}\text { Particle Length } \\
(\mathrm{mm})\end{array}$ & $\begin{array}{l}\text { Mass } \\
\text { (g) }\end{array}$ & \% quantity & \% by mass \\
\hline Small $(\leq 4 \mathrm{~mm})$ & 0.8 & 50 & 17.02 \\
Medium $(\leq 8 \mathrm{~mm})$ & 1.2 & 28 & 25.53 \\
Large $(>9 \mathrm{~mm})$ & 2.7 & 22 & 57.45 \\
\hline
\end{tabular}




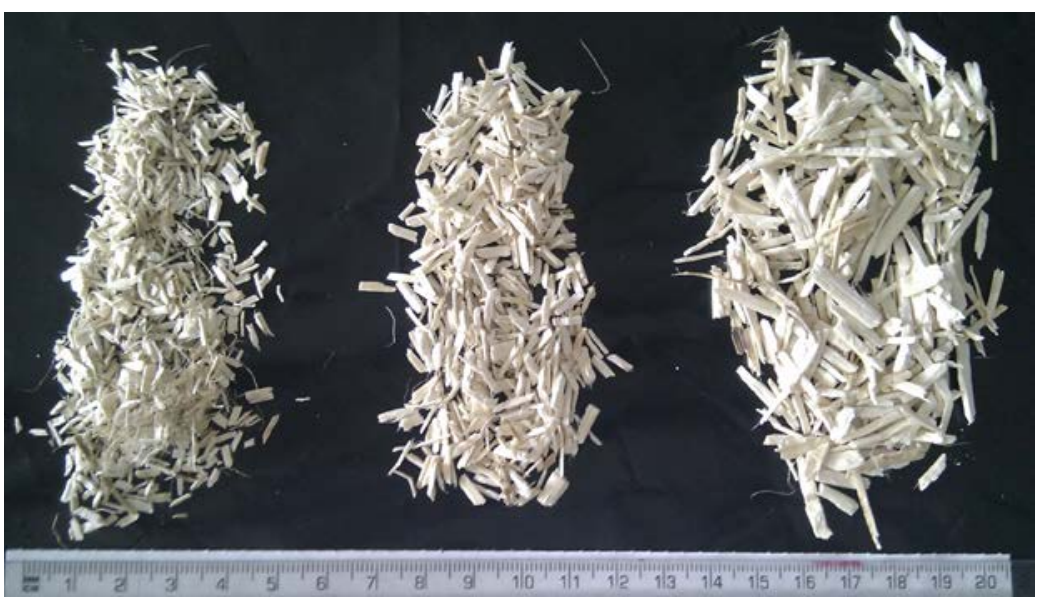

167 Figure 1. Three sizes of hemp particles.

168

169

170

171 were used. For comparison purposes, a binder including Portland cement (CEM I)

173 lime, hemp concrete binder typically used on site - termed 'builder's mix' (BM) in this

175

176 Four hemp concrete walls include pozzolans (Table 3). Two pozzolans - metakaolin

177 (M) and GGBS (G) - were identified as having potential for use in hemp-lime

178 concrete on account of their fast setting and high reactivity [52]. The chemical

179 composition of the pozzolans, assessed through spectroscopy as previously outlined

180 [16], are given in Table 2. The pozzolans' chemical composition, amorphousness and

181 surface area are described in other work [17]. Two other hemp concrete walls

$182(M+W R, G+W R)$ include a water retainer, methyl celulose, to retain water in the 
183 binder and reduce the water absorbed by the hemp [53].

184 Table 2 Chemical composition of GGBS and Metakaolin [16]

\begin{tabular}{lll}
\hline Composition & GGBS (\%) & \multicolumn{2}{l}{ Metakaolin (\%) } \\
\hline $\mathrm{CaO}$ & 39.27 & -- \\
$\mathrm{SiO}_{2}$ & 34.14 & 51.37 \\
$\mathrm{Al}_{2} \mathrm{O}_{3}$ & 13.85 & 45.26 \\
$\mathrm{Fe}_{2} \mathrm{O}_{3}$ & 0.41 & 0.52 \\
$\mathrm{SO}_{3}$ & 2.43 & -- \\
$\mathrm{MgO}$ & 8.63 & 0.55 \\
\hline
\end{tabular}

\subsubsection{HEMP CONCRETE}

186 Six hemp concrete walls with each of the six binder compositions as outlined in Table

1873 are tested. Each wall in the sample set can be segregated into two distinct sets;

188 those including cement and hydraulic lime (BM, CM) and those comprising hydrated

189 lime and pozzolan binders ( $G, M, G+W R, M+W R$ ). SEM images of selected samples 190 are shown in Figure 2.

Table 3. Composition and properties of hemp concrete walls.

\begin{tabular}{|l|l|l|l|l|}
\hline Wall & $\begin{array}{l}\text { Specimen } \\
\text { Composition }\end{array}$ & $\begin{array}{l}\text { Binder composition } \\
\text { (\% by weight) }\end{array}$ & $\begin{array}{l}\text { Binder: Hemp: } \\
\text { Water (by } \\
\text { weight) }\end{array}$ & $\begin{array}{l}\text { Density } \\
\left(\mathbf{k g} / \mathbf{m}^{\mathbf{3}}\right)\end{array}$ \\
\hline $\begin{array}{l}\text { Hemp } \\
\text { concrete } \\
\text { including } \\
\text { hydraulic } \\
\text { binders }\end{array}$ & $\begin{array}{l}\text { BM } \\
\text { (Builder's Mix) }\end{array}$ & $\begin{array}{l}\text { CM CL90s, 20\% NHL3.5, } \\
10 \% \text { CEM I }\end{array}$ & $2: 1: 2.9$ & 573 \\
\cline { 2 - 5 } & (Commercial Mix) & $100 \%$ commercial binder & $2: 1: 3.1$ & 583 \\
\hline
\end{tabular}




\begin{tabular}{|c|c|c|c|c|}
\hline \multirow{4}{*}{$\begin{array}{l}\text { Hemp } \\
\text { concrete } \\
\text { made with } \\
\text { hydrated } \\
\text { lime and } \\
\text { pozzolans }\end{array}$} & $\begin{array}{l}\mathrm{G} \\
\text { (GGBS) }\end{array}$ & 70\% CL90s, 30\% GGBS & 2:1:3.3 & 505 \\
\hline & $\begin{array}{l}\text { M } \\
\text { (Metakaolin) }\end{array}$ & $\begin{array}{l}80 \% \text { CL90s, } 20 \% \\
\text { metakaolin }\end{array}$ & 2:1:3.1 & 493 \\
\hline & $\begin{array}{l}\text { G+WR } \\
\text { (GGBS and water } \\
\text { retainer) }\end{array}$ & $\begin{array}{l}\text { 70\% CL90s, 30\% GGBS, } \\
0.5 \% \text { methyl cellulose }\end{array}$ & 2:1:3.1 & 522 \\
\hline & $\begin{array}{l}\text { M+WR } \\
\text { (Metakaolin and } \\
\text { water retainer) }\end{array}$ & $\begin{array}{l}80 \% \text { CL90s, } 20 \% \text { GGBS, } \\
0.5 \% \text { methyl cellulose }\end{array}$ & 2:1:3.1 & 469 \\
\hline
\end{tabular}

The density of the concretes bound with hydraulic lime and cement binders (BM,

193 CM) were consistently higher than the densities of samples bound with hydrated

194 lime and pozzolan binders. The porosity was measured by water displacement 195 pycnometry [52], on samples of each mix cast contemporaneously with the panels.

196 The porosity for all the samples was $72 \% \pm 2 \%$. SEM analysis of the hemp-concrete

197 [17] evidenced their pore structure. Significant hydrates filling pores are evident in 198 the concretes with hydraulic and cementicious binders while the lime-pozzolan 199 binders were largely carbonated with infrequent hydrates [16].
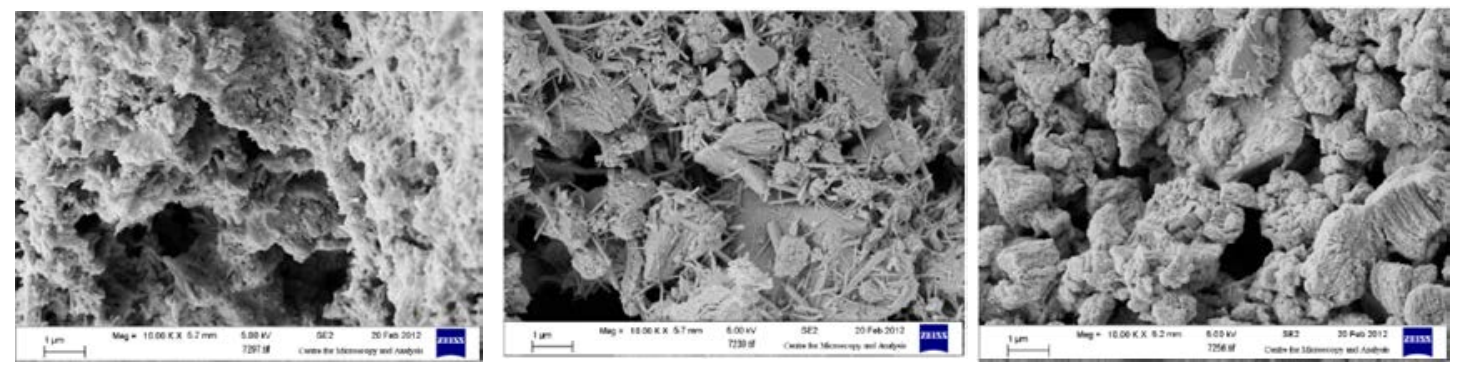

Figure 2. SEM images of (left) BM, (middle) CM, (right) G binder hemp concrete matrices.

\subsubsection{HEMP RENDER}

203 Hemp-lime render mixes have been investigated for the development of a 
breathable, thermal insulation render for retrofitting [54]. This study investigates renders mixed in two ratios: 2:1 and 1:1.25 (lime to hemp ratio by weight). The

206 former of these is a commonly used mix, and the latter is investigated to assess the impact of a greater proportion of hemp in the mix. 10 and $20 \mathrm{~mm}$ renders were applied to the hemp lime concrete wall containing hydrated lime, metakaolin and methyl cellulose (M+WR in Table 3 ) and the sound performance tested.
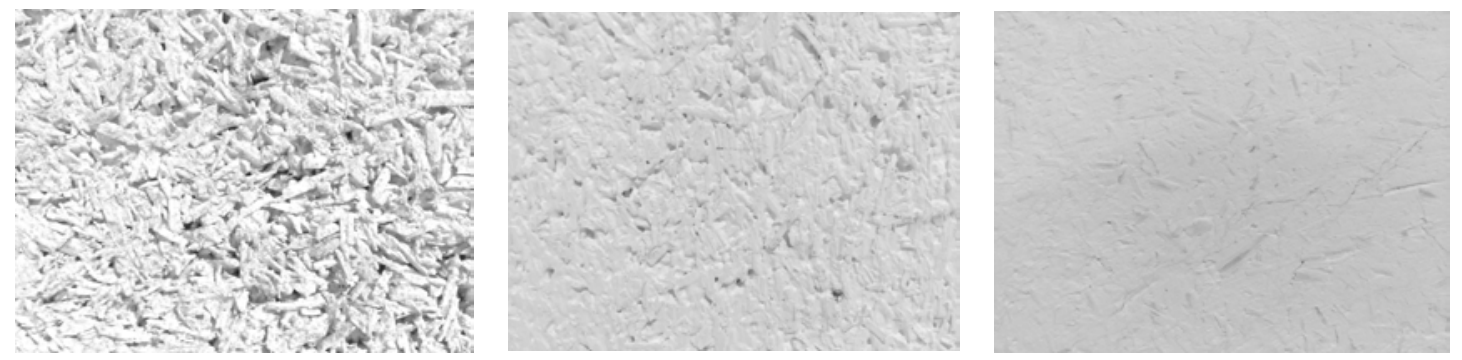

Figure 3. Surface finishes of (left) unfinished hemp-lime concrete, (middle) 1:1.25 lime-hemp render, (right) 2:1 lime-hemp render.

\subsection{IMPEDANCE TUBE TESTING}

An impedance tube with $70 \mathrm{~mm}$ diameter is tightly contacted to the wall surface. A

215 white noise signal is generated using a B\&K 1405 noise generator, amplified and transmitted through a speaker down the length of impedance tube.

217 Tests were undertaken at the centre point and repeated in multiple locations in a

$218300 \mathrm{~mm}$ radius around the centre. An average value was taken across six tests. For 219 each panel the standard deviation between tests was less than $5 \%$. Acoustic 220 absorption coefficients were calculated in the frequency range $332 \mathrm{~Hz}$ up to $2865 \mathrm{~Hz}$ 221 with cut-off frequencies defined in the standards [43] and literature [55], for the 222 distance between the microphones $(43 \mathrm{~mm})$ and length of tube $(963 \mathrm{~mm})$. In the 223 BB93 guideline document for acoustics in schools, published by the BRE [26], the 
reverberation time criteria are set in terms of the average value of the three octave

225 bands, $500 \mathrm{~Hz}, 1 \mathrm{kHz}$, and $2 \mathrm{kHz}$, denoted as mid frequency reverberation time $T_{m f}$

2263 RESULTS

227 The acoustic characteristics of hemp-lime concrete were discerned through analysis

228 of the absorption profile across the range of frequencies up to $2500 \mathrm{~Hz}$. Results for 229 loose hemp shiv, unrendered and rendered hemp-lime concrete walls are discussed 230 in the context of material density and porosity.

\subsection{ACOUStic Characterisation of LoOSE HeMP}

232 The absorption characteristics are tested on loose hemp, without binder for different

233 levels of compaction and depth of shiv and various sizes of particles similar to the 234 study of Gle et al. [34].

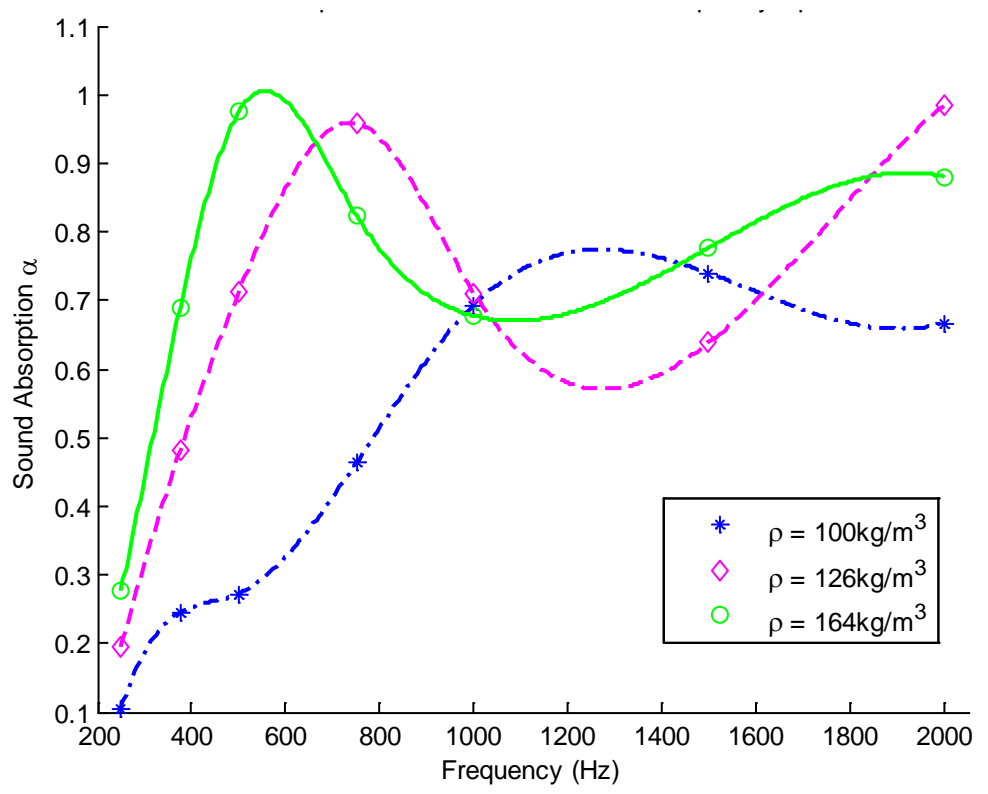

237 Figure 4. Sound absoption characteristics of loose hemp shiv, for different levels of compaction. 
238 Owing to the porous nature of the loose hemp, sound absorption is high across the 239 range of frequencies, similar to other unbonded bio-based materials [56]. A peak in 240 the $400-600 \mathrm{~Hz}$ range is observed as previously reported [34].

241 Similarly, increasing the depth of shiv shifts the absorption curve to the lower 242 frequencies. However, changing the degree of compaction of loose shiv has the 243 greatest effect on the sound absorption profile across the range of frequencies. 244 Compaction changes the pore size distribution and shifts the acoustic absorption 245 curve, including first and second peaks, toward the low frequencies enhancing the 246 amplitude of the first peak as is shown in Figure 4.

2473.2 Acoustic Characterisation of HEMP-LIME CONCRETES

248 Table 4 documents the sound absorption coefficient at the $1 / 3$ octave frequencies $249500 \mathrm{~Hz}, 1000 \mathrm{~Hz}$ and $2000 \mathrm{~Hz}$, for all six hemp concretes. The sound absorption 250 frequency in the range $400-2000 \mathrm{~Hz}$ is plotted in Figure 5.

251 Table 4. Sound absorption coefficients of unrendered hemp-lime concrete walls with various binders.

\begin{tabular}{|c|c|c|c|c|}
\hline Binder & $\begin{array}{l}\rho \\
\left(\mathrm{kg} / \mathrm{m}^{3}\right)\end{array}$ & $\alpha: 500 \mathrm{~Hz}$ & $\alpha: 1 K \mathrm{~Hz}$ & $\alpha: 2 K \mathrm{~Hz}$ \\
\hline Builders mix (BM) & 573 & 0.32 & 0.24 & 0.26 \\
\hline Commercial mix (CM) & 583 & 0.45 & 0.37 & 0.39 \\
\hline GGBS (G) & 505 & 0.49 & 0.42 & 0.44 \\
\hline Metakaolin (M) & 493 & 0.46 & 0.39 & 0.44 \\
\hline $\begin{array}{l}\text { GGBS \& water } \\
\text { retainer (G+WR) }\end{array}$ & 522 & 0.52 & 0.45 & 0.53 \\
\hline $\begin{array}{l}\text { Metakaolin \& water } \\
\text { retainer (M+WR) }\end{array}$ & 469 & 0.42 & 0.37 & 0.41 \\
\hline
\end{tabular}




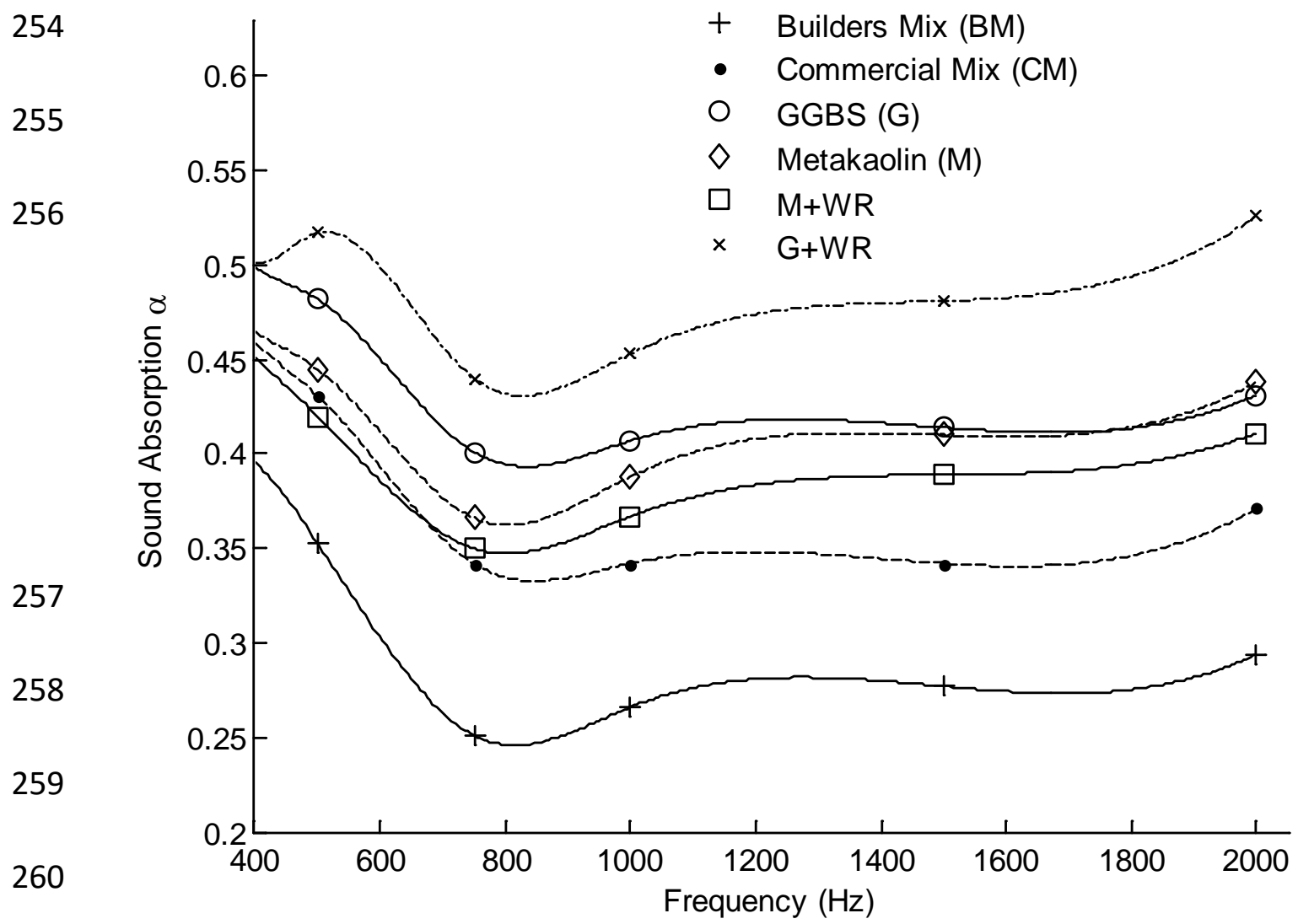

261 Figure 5. Sound absorption of hemp-lime concrete walls with different binders in the range 500-2000Hz.

262 The hemp with BM binder, which includes $10 \%$ portland cement, has the lowest

263 sound absorption across all frequencies. The hydraulic lime commercial binder (CM)

264 is also lower than both lime-pozzolan binders which exhibit similar characteristic

265 profiles. The densities of the lime-pozzolan concretes are lower, implying an inverse

266 relationship between sound absorption and hemp concrete density. Absorption

267 coefficients for all samples are higher in the low frequencies, dip at approximately $268750 \mathrm{~Hz}$ and reach almost constant values in the $1000-2000 \mathrm{~Hz}$ range. Density and 269 open porosity are inversely related [37], and this could explain the higher sound 
270 absorption coefficients exhibited by the pozzolanic binders across the range of 271 frequencies.

\subsection{Acoustic Characterisation of Rendered Hemp-Lime Concrete}

273 The change in the acoustic absorption characteristic of hemp-lime concrete walls,

274 when rendered with 10 and $20 \mathrm{~mm}$ hemp-lime renders, is documented in Table 5,

275 for 2 different render mixes. The absorption coefficients for the unrendered

276 metakaolin with water retainer $(M+W R)$ bound hemp concrete are plotted in Figure

277 6. For clarity only the walls with the $10 \mathrm{~mm}$ renders are plotted.

278 Table 5. Sound absorption coefficients of rendered hemp-lime concrete walls.

\begin{tabular}{llll}
\hline Binder & $\alpha: 500 \mathrm{~Hz}$ & $\alpha: 1 \mathrm{kHz}$ & $\alpha: 2 \mathrm{kHz}$ \\
\hline Unrendered Control Wall (M+WR) & 0.42 & 0.37 & 0.41 \\
10mm Hemp-Lime Render 1.25:1 & 0.31 & 0.18 & 0.18 \\
10mm Hemp-Lime Render 1:2 & 0.28 & 0.17 & 0.22 \\
20mm Hemp-Lime Render 1.25:1 & 0.29 & 0.16 & 0.18 \\
20mm Hemp-Lime Render 1:2 & 0.28 & 0.15 & 0.19 \\
\hline
\end{tabular}




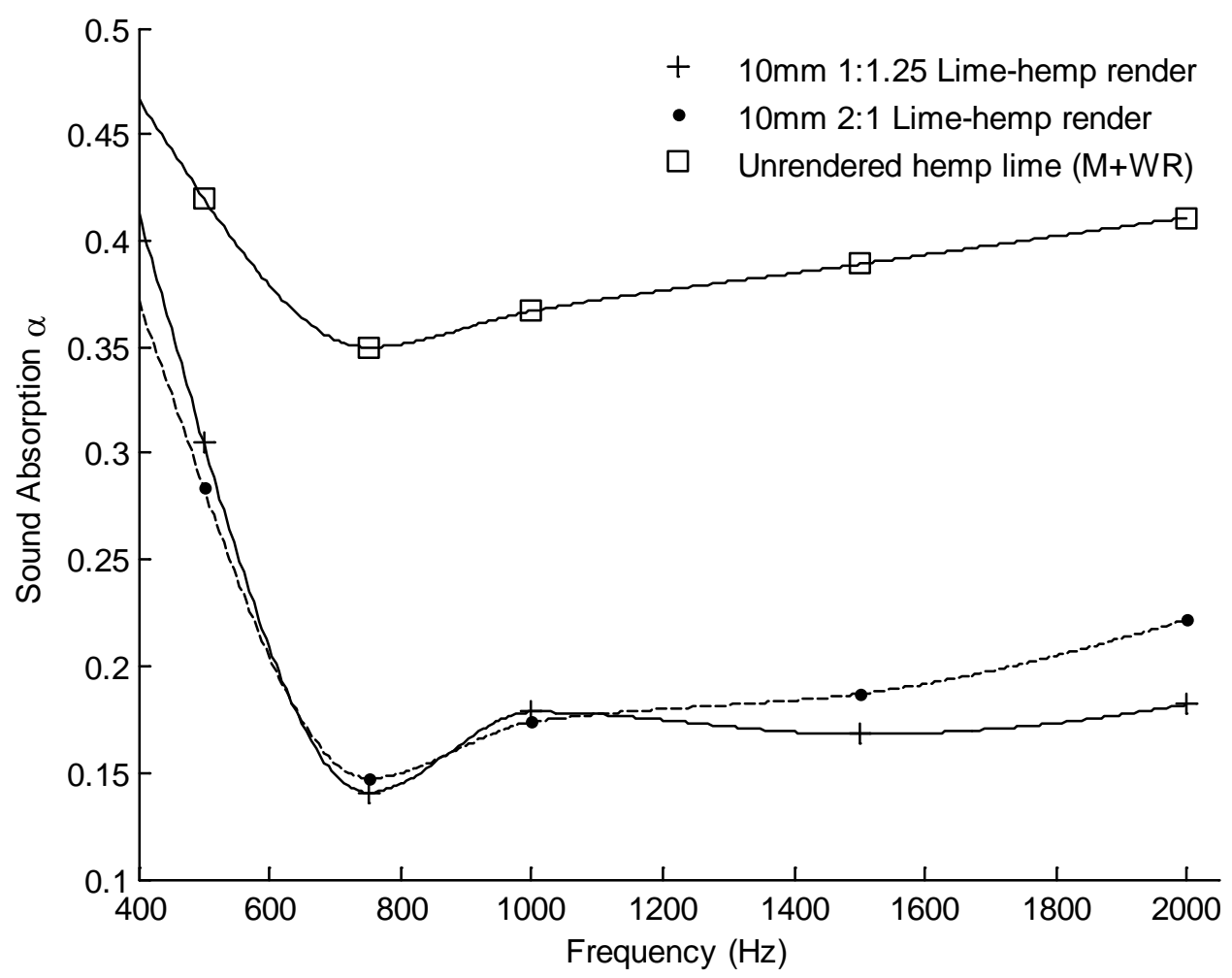

Figure 6. Sound absorption of rendered hemp-lime concrete walls in the range $500-2000 \mathrm{~Hz}$.

283 The sound absorption coefficient is reduced consistently across the range of 284 frequencies examined: over $50 \%$ at the majority of frequencies. The $20 \mathrm{~mm}$ render 285 (Table 5) produced a slight further reduction in acoustic absorption capability of the 286 hemp-lime walls. 
288 Table 6: Table of nomenclature

\begin{tabular}{|c|c|}
\hline Symbol & Meaning \\
\hline$\alpha$ & Absorbance coefficient \\
\hline$\alpha_{\infty}$ & High frequency tortuosity \\
\hline$\Phi$ & Porosity \\
\hline$\rho$ & Bulk density \\
\hline$\rho_{f}$ & Fibre density \\
\hline$\rho_{0}$ & Air density \\
\hline$\rho_{e q}$ & Equivalent density \\
\hline$\omega$ & Angular frequency \\
\hline$\sigma$ & Airflow resistivity \\
\hline$T$ & $\begin{array}{l}\text { Ratio between the first and zeroth order } \\
\text { Bessel functions of the first type }\end{array}$ \\
\hline$\gamma$ & $\begin{array}{l}\text { Ratio of specific heat capacities for air (with } \\
\text { respect to pressure and volume) }\end{array}$ \\
\hline$P_{0}$ & Mean air pressure \\
\hline$k$ & Wavenumber \\
\hline$K_{e q}$ & Equivalent stiffness \\
\hline I & Sample thickness \\
\hline$s$ & Shape factor \\
\hline$Z$ & Sample surface impedance \\
\hline$Z_{0}$ & Impedance of air \\
\hline$Z_{c}$ & Characteristic impedance of the sample \\
\hline
\end{tabular}

291 Developing a predictive model for the absorbance of media with multi-scale porosity 
295 from the porosity and resistivity, and report good agreement between that model 296 and experimental results for loose hemp shiv. The present work follows this 297 approach, using the relationships developed by Gle et al. between density, porosity 298 and resistivity to produce predictions of the absorbance coefficient of loose hemp 299 shiv. The porosity is calculated from the measured densities as:

$$
\Phi=1-\frac{\rho}{\rho_{f}}
$$

301 The airflow resistivities are extrapolated from the results from Gle et al. relating 302 density to resistivity, as shown in Figure 7.

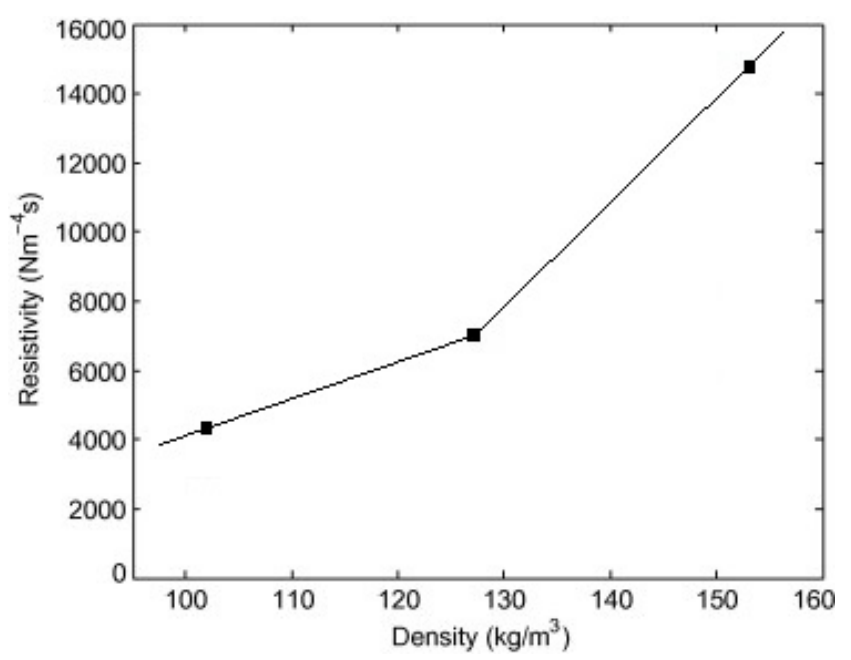

Figure 7 Relationship between density and airflow resistivity from Gle et al. (linear extrapolation lines added).

305 Both the porosity and resistivity depend more strongly on the degree of compaction than they do on the properties of individual particles. From these relationships, the model parameters for the present shiv samples are shown in Table 7. 


\begin{tabular}{llll}
\hline Sample & $\begin{array}{c}\text { Density } \\
\mathbf{k g} / \mathbf{m}^{3}\end{array}$ & Porosity \% & Resistivity \\
\hline Loose & 100 & 91 & 4000 \\
Medium & 126 & 88 & 6600 \\
Dense & 164 & 85 & 18600 \\
\hline
\end{tabular}

309

310 This allows the prediction of the absorbance based on the Allard-Biot model as

311 presented by Gle et al. The high-frequency tortuosity is left as a fitting parameter to

312 be determined. The model is a model for the absorbance coefficient based on the

313 equivalent density and stiffness.

314

$$
\alpha=1-\left|\frac{Z-Z_{0}}{Z+Z_{0}}\right|^{2}
$$

315 With $Z$ and $Z_{C}$ calculated as follows:

316

$$
\rho_{e q}=\frac{\rho_{0} \alpha_{\infty}}{\phi}-\frac{i \sigma}{\omega} F(\lambda)
$$

$$
K_{e q}=\frac{\gamma P_{0}}{\phi}\left(1+2(\gamma-1) \frac{T\left(\lambda \sqrt{i N_{P r}}\right)}{\lambda \sqrt{i N_{P r}}}\right)^{-1}
$$

$$
\lambda=\sqrt{\frac{8 s^{2} \alpha_{\infty} \rho_{0} \omega}{\sigma \phi}}
$$

$$
Z_{c}=\sqrt{\rho_{e q} K_{e q}}
$$




$$
k=\omega \sqrt{\frac{\rho_{e q}}{K_{e q}}}
$$

$$
Z=-i Z_{c} \cot (k l)
$$

323 This allows the absorption coefficient to be calculated as shown in Equation 1.

324 Gle et al. present the graph shown in Figure 8 for a particular sample of loose shiv.

325 Predictions of the absorption for the medium-compaction shiv in the present test are

326 shown in Figure 9 with $\alpha_{\infty}=2.3$. This is the high-frequency tortuosity found by Gle

327 et. al.; however, the model provides a much better match to the present data using

$328 \alpha_{\infty}=4$ (also shown in Figure 9).

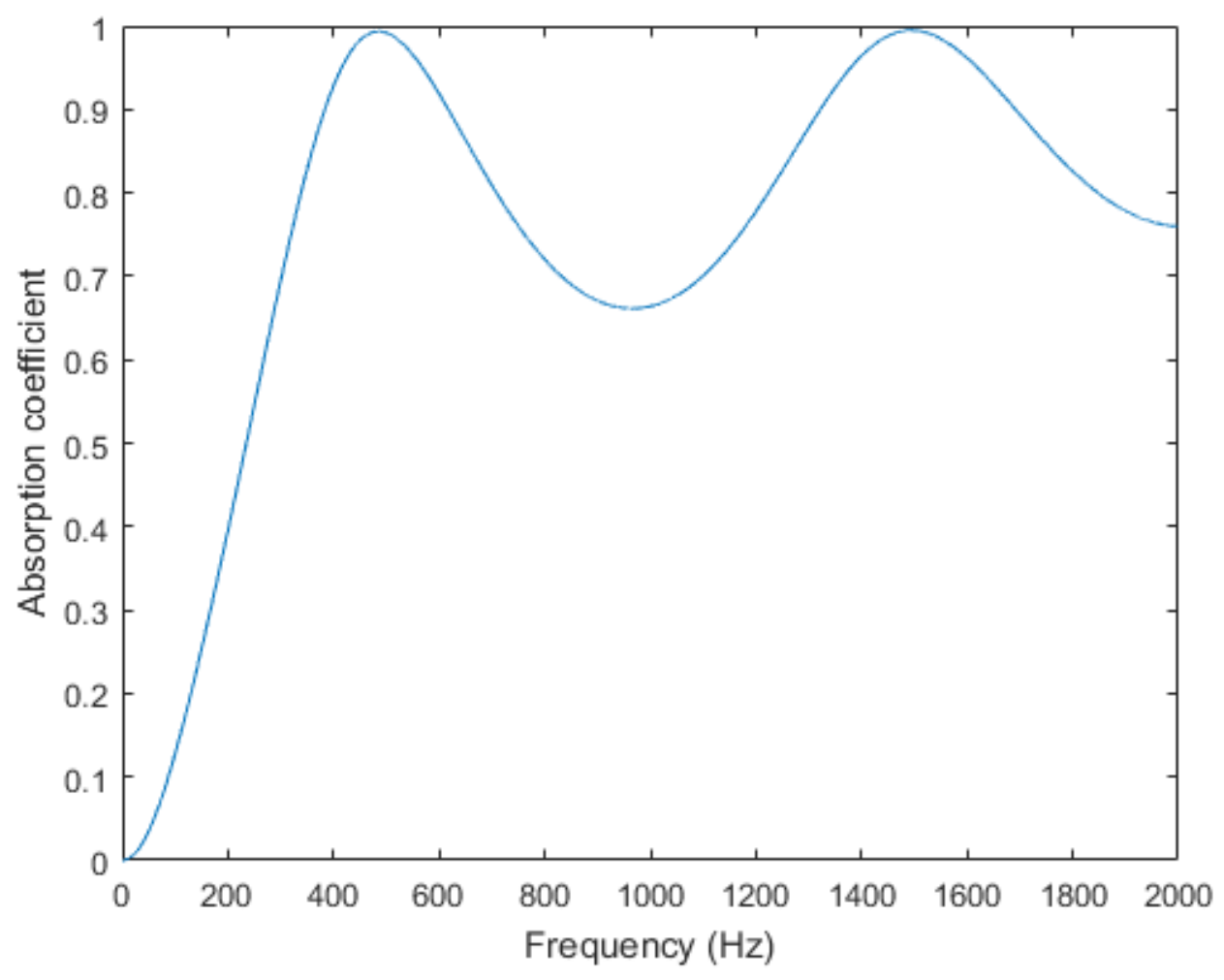




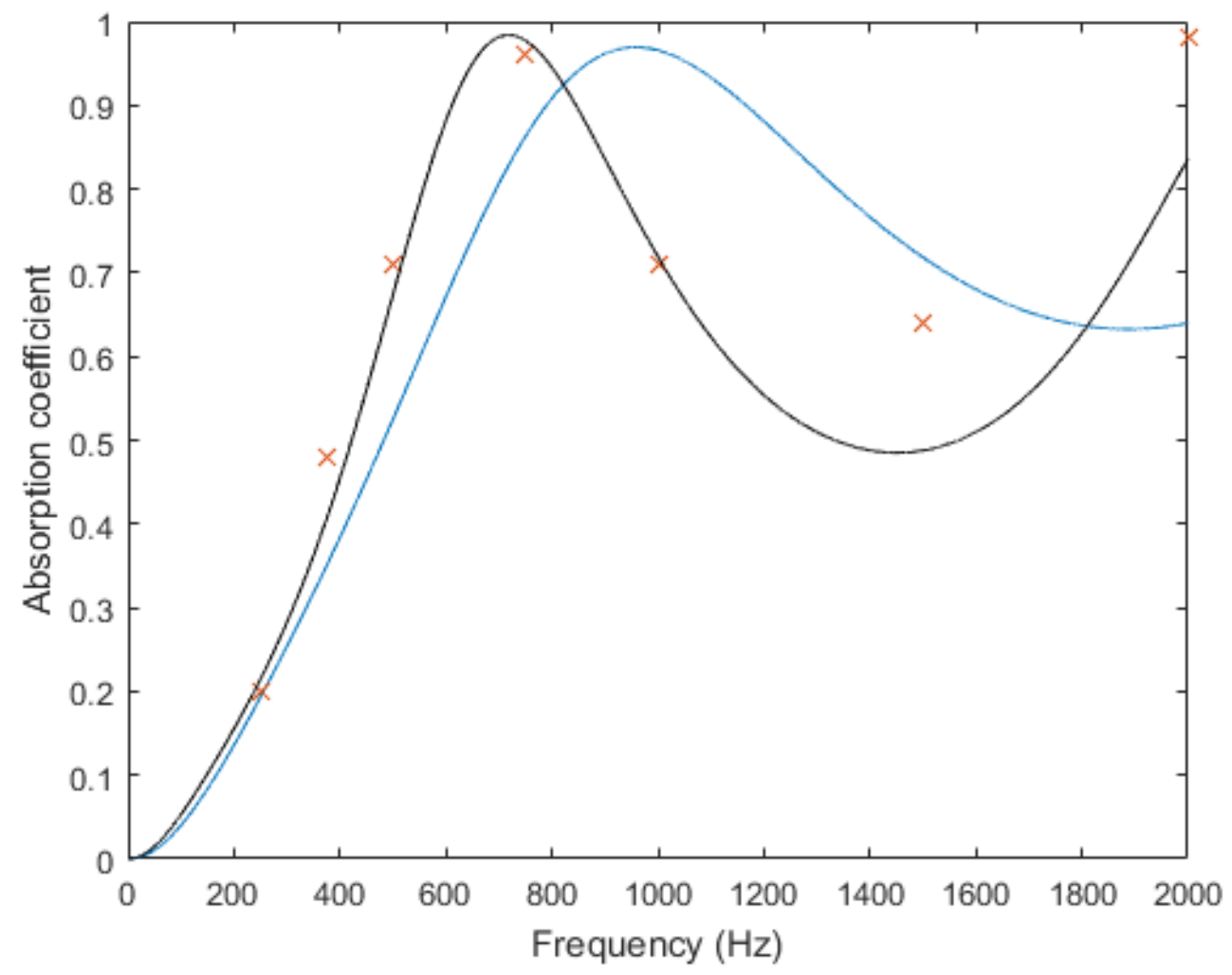

Figure 9 Predicted absorbance for $\alpha_{\infty}=2.3$ (blue) and $\alpha_{\infty}=4$ (black) with experimental results (red) for medium-density loose shiv.

335 A similar process is used for each loose shiv sample. The results from the low and

336 high density shives, with the respective model parameters, are plotted in Figure 10.

337 The parameters used for this figure, and those that follow, are given below:

$\Phi$

$\rho_{0}$

$\sigma$

Y

$P_{0}$

I

$s$
As measured (Table 4)

$1.2 \mathrm{~kg} / \mathrm{m}^{3}$

$25 \mathrm{kN} \mathrm{m}^{-4} \mathrm{~s}$

1.4

$101 \mathrm{kPa}$

$0.3 \mathrm{~m}$ 


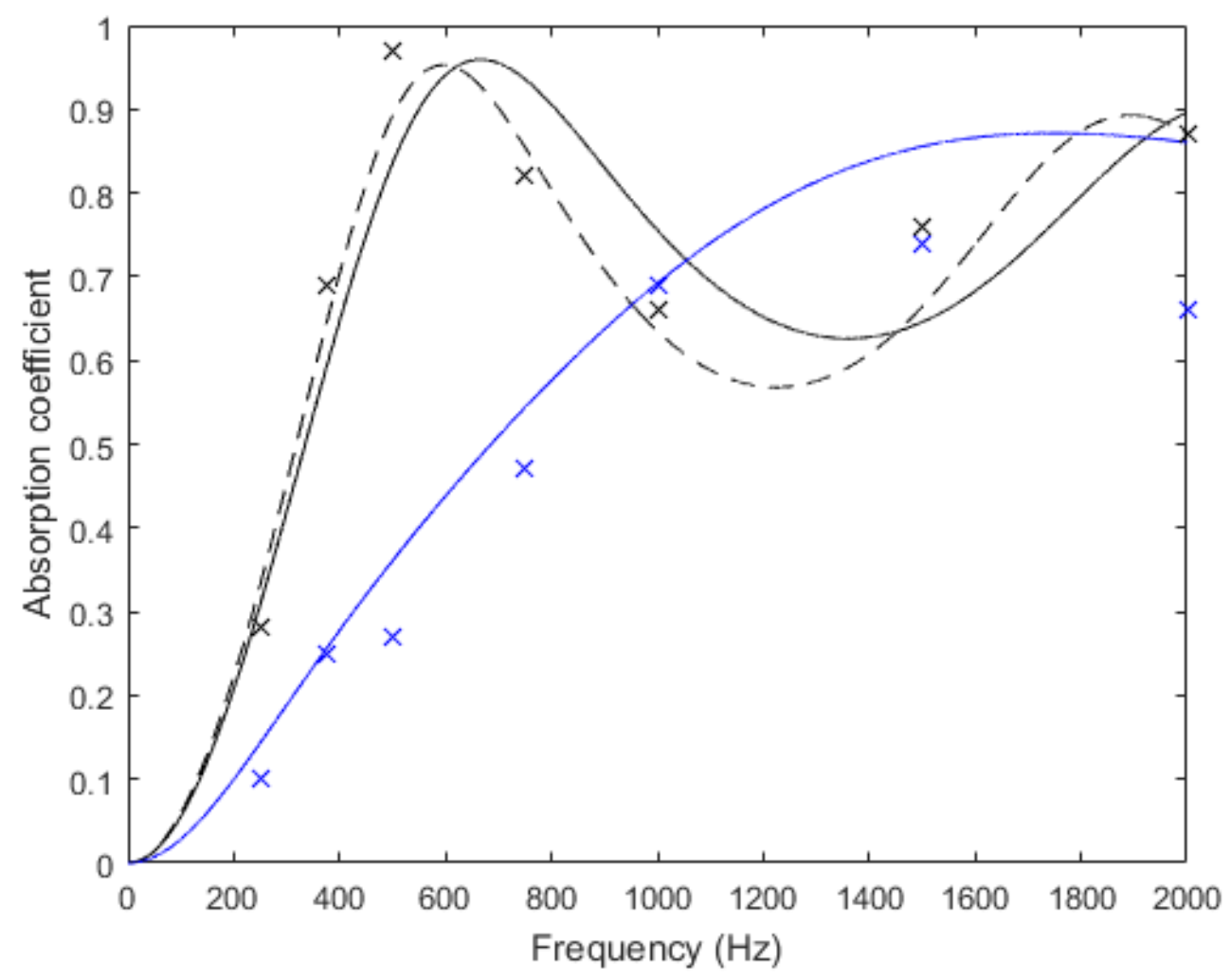

Figure 10 Low-density shiv ( $\alpha_{\infty}=1$, blue) and high-density shiv $\left(\alpha_{\infty}=4\right.$, solid black, and $\alpha_{\infty}=5$, dashed black).

342 The results above suggest a very high value for the tortuosity is needed to in order

343 for the model to fit the data. The work of Jaouen, Boutin and Geindreau suggests a

344 physical upper limit for the high-frequency tortuosity of around 3. Together with the

345 results, this suggests that the present model perhaps does not accurately capture

346 the true multi-scale nature of the porosity, but more work is needed to clarify this. It

347 is possible that the tortuosity is indeed higher when using a mixture of shiv particle

348 sizes, compared to the more uniform distributions used by Gle et. al. (2013, and also

349 in earlier work), although the low-density case would seem to contradict this. It is 
350 possible that the greater degree of compaction in the higher-density cases leads to

351 breaking of some hemp particles, a reduction in average size, and hence an increase

352 in tortuosity.

$353 \quad 4.2$ MODELLING OF HEMP-LIME CONCRETE

354 The Biot-Allard model, which provides a good model for hemp shiv, has previously

355 been shown to be a poor model of the acoustic behaviour of hemp-lime concretes

356 [34]. Gle et. al. use Johnson's model, which gives a different form for the dynamic 357 density, and find much better agreement with experimental results. However, the 358 present study could not find physically possible values of the parameters for the 359 Johnson model that are in agreement with the experimental results. The results 360 presented by Gle et al for concrete extend only up to $500 \mathrm{~Hz}$; in the present study, in 361 particular, the results for all the concretes tested show a substantial fall in 362 absorption coefficient from 500 to $750 \mathrm{~Hz}$. The Johnson model does not adequately 363 describe the absorption in this frequency range, and further modelling work is 364 required to identify a suitable model for the acoustic behaviour of hemp-lime 365 concretes in this frequency range. 


\section{DISCUSSION}

\subsection{Acoustic Absorption Of HeMP-LIME}

368 The hemp concretes investigated exhibit significant sound absorption across the

369 tested frequency range and are characterized by absorption coefficients between

$370 \quad 0.24$ and 0.53 . Hemp concretes with lime binders exhibit significantly higher sound

371 absorption coefficients than binders including cement. The results also showed that 372 hemp concretes with hydrated lime-pozzolan binders have a greater sound

373 absorption than hemp concretes bound with hydraulic binders. This indicates that 374 there is an inverse relationship between sound absorption and hydraulic content. 375 These results align with those of Gle et al. [34], who showed concretes with quick 376 natural cement binders to be significantly less absorptive than hydraulic lime binders 377 in the frequency range up to $500 \mathrm{~Hz}$. This indicates that there is an inverse 378 relationship between sound absorption and hydraulic content although this finding 379 may be influenced by density in this study.

380 Rendering the hemp concrete wall reduced the open surface porosity resulting in a

381 significant reduction in its sound absorption ability. Greater relative reduction in 382 sound absorption is evident in the higher frequencies. Although the two renders 383 examined varied in quantity of hemp relative to lime, no significant variation in 384 sound absorption is observed between both.

385 It is difficult to directly compare the sound absorption characteristics of different materials, as the absorption coefficient is not a single-valued, intrinsic material property but depends strongly on frequency and material thickness. Nevertheless, 
388 hemp-lime concrete displays good sound absorption when compared to other 389 common building materials [41], although it exhibits sound absorption coefficients 390 slightly lower than porous concrete [30] and fair faced concrete block [41]. When 391 compared to the range of sound absorption materials, the unrendered hemp-lime 392 falls into the absorption class $D$ for building materials [57]. It drops into the 393 absorption class $E$ when rendered which is low with respect to commercial sound 394 absorption panels, but high with respect to standard wall types.

395 Previous work on the acoustic absorption of plant fibres has generally focussed on 396 the properties of the loose fibres or wool-type insulation products, rather than 397 bound or rendered products as in the present study; and results presented are 398 sometimes questionable. A review article by Asdrubali et al [56] uncritically presents 399 implausible results, such as absorption coefficients significantly greater than 1, 400 indicating imprecise measurement aparatus. Although Asdrubali's review has been 401 cited as a reference for absorption coefficients, their paper simply gives a value of 4020.6 for the absorption coefficient of hemp (at $500 \mathrm{~Hz}$ ), when the present study shows 403 significant variation depending on density. Despite the caveats noted, some typical 404 results for porous concrete and a selection of natural materials are shown in Table 8 405 for comparison purposes. For ease of comparison, this table shows only the NRC 406 values for each material - these are calculated by taking the mean of the absorption 407 coefficients at 500, 1000 and $2000 \mathrm{~Hz}$, rounded to the nearest 0.05 . 


\begin{tabular}{lll}
\hline Material & NRC & Data source \\
\hline Unrendered hemp concrete & 0.4 & Present study \\
Rendered hemp concrete (mean value) & 0.2 & Present study \\
Porous concrete (sample A) & 0.6 & {$[30]$} \\
Porous concrete (sample B) & 0.25 & {$[30]$} \\
Hemp & 0.25 & {$[58]$} \\
Cork & 0.2 & {$[58]$} \\
Wood fibres & 0.5 & {$[58]$} \\
Sheep wool & 0.55 & {$[58]$} \\
Kenaf & 0.6 & {$[58]$} \\
Coconut & 0.65 & {$[58]$}
\end{tabular}

412

\section{$413 \quad 5.2$ ASSESSMENT OF CONSTRUCTIONS USING HEMP-LIME}

414 Reverberation time ( $T_{R}$, the time taken for a sound to decay by $\left.60 \mathrm{~dB}\right)$ is a salient

415 criterion in the acoustic design of spaces. Dependent on room geometry and 416 absorption, it is used to describe the rate at which sound decays, and is described by 417 the Sabine formula[51]:

$$
T_{R}=0.163^{V} / A
$$

419 where $V$ is the volume of the room, and $A=\alpha_{1} S_{1}+\alpha_{2} S_{2}+\alpha_{3} S_{3}+\ldots$, where $S_{1-n}$ are the 420 different room surfaces and $\alpha_{1-n}$ their corresponding sound absorption coefficients. 
421 Given the propensity for smooth, plastered or glazed wall surfaces in contemporary 422 architecture, acoustic absorption of surfaces is often quite low and $T_{R}$ can be long, 423 affecting intelligibility of speech and clarity of sound. The tendency is often to 424 concentrate sound absorbing materials on the ceiling; however, this can be of 425 limited impact and ignores the multiple reflections between parallel walls in a 426 rectangular floor plan [29]. Also, exploiting the thermal mass of building construction 427 is often key to passive and low energy strategies for indoor climate control of 428 buildings. Night cooling of extensive thermal mass requires exposure of fair-faced 429 concrete including soffits and floors. Hence the energy/climate concept can conflict 430 with the acoustic concept and prohibit extensive cladding of ceilings for acoustic 431 absorption.

432 Optimum reverberation times differ depending on the space function ranging from $433 \quad 0.4-0.7 \mathrm{~s}$ for classrooms, $0.8-1.2 \mathrm{~s}$ for theatres and $1.4 \mathrm{~s}$ upwards for churches and 434 cathedrals [29], and hemp-lime walls (whether rendered or unrendered) offer 435 potential to reduce reverberation time to that specified in standard and guideline 436 documents. Taking school classrooms as an example, UK guideline documents 437 specify limits for the average value of octave bands at $500 \mathrm{~Hz}, 1000 \mathrm{~Hz}$ and $2000 \mathrm{~Hz}$, 438 denoted $T_{m f}$ [26]]. German guidelines DIN 18041 [27] specify $T_{R}$ of $0.5-0.7 \mathrm{~s}$ for 439 classrooms with room volume $150-250 \mathrm{~m}^{3}$ as typical. The unrendered hemp-lime 440 walls evaluated in this study can easily achieve these recommended reverberation 441 times for the typical range of classroom volumes. When considering the room 442 volume range $150-250 \mathrm{~m}^{3}$, and presuming an exposed masonry/concrete floor and 443 soffit ( $\alpha$ around 0.1 ), hemp lime-pozzolan concrete walls ( $\alpha$ in Table 3 ) can enable a 
$444 T_{m f}$ of $0.5-0.6 \mathrm{~s}$ with a good distribution of sound absorbing surfaces and no ceiling

445 or wall appendages. However, rendering of the hemp-lime walls reduces the

446 absorption ability significantly (Table 5 ). When rendered $T_{m f}$ increases to $1.2-1.7 \mathrm{~s}$.

447 Although this reverberation time is much lower than in rendered or painted walled

448 rooms it is outside the required values for classrooms; consequently, acoustic

449 treatment or additional sound absorbing panels will be required to meet guideline 450 values.

\subsection{LIMITATIONS OF THE IMPEDANCE TUBE METHOD}

453 There are some limitations associated with the impedance tube method of 454 calculation, principally that measurements are at normal incidence. Although this 455 condition is not commonly satisfied, characteristic impedance of a porous media can

456 be measured with the impedance tube and used to predict acoustic behavior of the 457 material at oblique incidence. The study is also limited to the range of frequencies 458 defined by the dimensions of impedance tube. The low frequency vowel sounds are 459 generally in the $125 \mathrm{~Hz}$ (men) $-265 \mathrm{~Hz}$ (children) range. However, recognition of 460 constants and speech formants whose energy is concentrated in the measured 461 frequencies of the speech spectrum, are key for speech intelligibility [26]. Complex 462 computer simulations using geometrical techniques such as ray tracing and the 463 mirror-source method are required to accurately predict the acoustic characteristics 464 of specifically designed spaces and sound environments. However, the acoustic 
465 quality of spaces can be approximated using reverberation time estimates $\left(T_{m f}\right)$ 466 when acoustic paramaters of construction materials $(\alpha)$ are characterised. 
467

468

469

470

471

472

473

474

475

In practice, the addition of a lime render finish to the hemp-lime composite wall presents a durable wall finish without significantly compromising the hygrothermal qualities of the hemp-lime construction. However, when hemp-lime walls are rendered the absorption coefficient reduces significantly. Buildings and rooms built using hemp concrete enable exposure of high sound absorbing surfaces, and hence low reverberation times, with a reduced need for additional acoustic treatment.

[1] L. Arnaud, Bio-aggregate-based Building Materials: Applications to Hemp Concretes. John Wiley \& Sons, 2013.

[2] T. Woolley, Low Impact Building: Housing using Renewable Materials. John Wiley \& Sons, 2013. 
[3] A. Shea, M. Lawrence, and P. Walker, "Hygrothermal performance of an experimental hemp-lime building," Constr. Build. Mater., vol. 36, pp. 270-275, Nov. 2012.

[4] B. Muller, "Thermal Hemp $04540 \mathrm{~mm}$ and $160 \mathrm{~mm}$ Type Hock Vertriebs GmbH \& Co.KG Measurement of sound absorption in the reverberation room according to DIN EN ISO 354 Test Report No. M52 297/1," 2006.

[5] J. P. Arenas and Crocker, "Recent Trends in Porous Sound-Absorbing Materials," Sound Vib., vol. 44, no. 7, pp. 12-17, 2010.

[6] M.-P. Boutin and C. Flamin, "Examination of the Environmental Characteristics of a Banked Hempcrete Wall on a Wooden Skeleton, by Lifecycle Analysis: Feedback on the LCA Experiment from 2005," in Bio-aggregate-based Building Materials, S. Amziane, L. Arnaud, and N. Challamel, Eds. John Wiley \& Sons, Inc., 2013, pp. 289-312.

[7] C. Ingrao, A. L. Giudice, J. Bacenetti, C. Tricase, G. Dotelli, M. Fiala, V. Siracusa, and C. Mbohwa, "Energy and environmental assessment of industrial hemp for building applications: A review," Renew. Sustain. Energy Rev., vol. 51, pp. 2942, Jun. 2015.

[8] N. Stevulova, J. Cigasova, A. Sicakova, and J. Junak, "Lightweight Composites Based on Rapidly Renewable Natural Resource," Chem. Eng. Trans., vol. 35, pp. 589-594, Jan. 2013.

[9] S. Pretot, F. Collet, and C. Garnier, "Life cycle assessment of a hemp concrete wall: Impact of thickness and coating," Build. Environ., vol. 72, pp. 223-231, Feb. 2014.

[10] J. Goggins, T. Keane, and A. Kelly, "The assessment of embodied energy in typical reinforced concrete building structures in Ireland," Energy Build., vol. 42, no. 5, pp. 735-744, May 2010.

[11] E. Heritage, Mortars, Renders and Plasters. Farnham; Burlington: Ashgate Publishing Limited, 2012.

[12] R. Siddique and J. Klaus, "Influence of metakaolin on the properties of mortar and concrete: A review," Appl. Clay Sci., vol. 43, no. 3-4, pp. 392-400, Mar. 2009.

[13] B. B. Sabir, S. Wild, and J. Bai, "Metakaolin and calcined clays as pozzolans for concrete: a review," Cem. Concr. Compos., vol. 23, no. 6, pp. 441-454, Dec. 2001.

[14] C.-Q. Lye, R. K. Dhir, and G. S. Ghataora, "Carbonation resistance of GGBS concrete," Mag. Concr. Res., pp. 1-34, Feb. 2016.

[15] M. Moranville-Regourd, "11 - Cements Made from Blastfurnace Slag," in Lea's Chemistry of Cement and Concrete (Fourth Edition), P. C. Hewlett, Ed. Oxford: Butterworth-Heinemann, 2003, pp. 637-678.

[16] R. Walker and S. Pavía, "Moisture transfer and thermal properties of hemplime concretes," Constr. Build. Mater., vol. 64, pp. 270-276, Aug. 2014.

[17] R. Walker, S. Pavia, and R. Mitchell, "Mechanical properties and durability of hemp-lime concretes," Constr. Build. Mater., vol. 61, pp. 340-348, Jun. 2014.

[18] P. de Bruijn and P. Johansson, "Moisture fixation and thermal properties of lime-hemp concrete," Constr. Build. Mater., vol. 47, pp. 1235-1242, Oct. 2013. 
[19] T. Lane, "Beer, cannabis, glue and a generous helping of lime," Building Design. [Online]. Available: http://www.bdonline.co.uk/beer-cannabis-glue-and-agenerous-helping-of-lime/3076861.article. [Accessed: 11-Nov-2014].

[20] World Health Organisation, Burden of disease from environmental noise. Quantification of healthy life years lost in Europe. 2011.

[21] J. M. Fields, "Reactions to environmental noise in an ambient noise context in residential areas," J. Acoust. Soc. Am., vol. 104, no. 4, pp. 2245-2260, Oct. 1998.

[22] D. S. Michaud, S. E. Keith, and D. McMurchy, "Noise annoyance in Canada," Noise Health, vol. 7, no. 27, pp. 39-47, Jun. 2005.

[23] W. Babisch, "Road traffic noise and cardiovascular risk," Noise Health, vol. 10, no. 38, pp. 27-33, Mar. 2008.

[24] O. Kinnane, M. Dyer, and T. Grey, "Energy and environmental forensic analysis of public buildings.," Eng. Sustain. Proc. Inst. Civ. Eng., vol. 167, no. 4, 2014.

[25] A. Leaman and B. Bordass, "Assessing building performance in use 4: the Probe occupant surveys and their implications," Build. Res. Inf., vol. 29, no. 2, pp. 129143, Mar. 2001.

[26] Department for Education, "Acoustic design of schools: performance standards 2014." [Online]. Available: http://www.bre.co.uk/page.jsp?id=384. [Accessed: 16-Nov-2014].

[27] DIN 18041:2004-05, Acoustical quality in small to medium-sized rooms. Beuth, 2004.

[28] G. W. Evans, S. Hygge, and M. Bullinger, "Chronic Noise and Psychological Stress," Psychol. Sci., vol. 6, no. 6, pp. 333-338, Nov. 1995.

[29] E. Mommertz, Acoustics and Sound Insulation. Berlin: Birkhauser, 2008.

[30] S. B. Park, D. S. Seo, and J. Lee, "Studies on the sound absorption characteristics of porous concrete based on the content of recycled aggregate and target void ratio," Cem. Concr. Res., vol. 35, no. 9, pp. 1846-1854, Sep. 2005.

[31] A. Laukaitis and B. Fiks, "Acoustical properties of aerated autoclaved concrete," Appl. Acoust., vol. 67, no. 3, pp. 284-296, Mar. 2006.

[32] N. Holmes, A. Browne, and C. Montague, "Acoustic properties of concrete panels with crumb rubber as a fine aggregate replacement," Constr. Build. Mater., vol. 73, pp. 195-204, Dec. 2014.

[33] M. E. Delany and E. N. Bazley, "Acoustical properties of fibrous absorbent materials," Appl. Acoust., vol. 3, no. 2, pp. 105-116, Apr. 1970.

[34] P. Glé, E. Gourdon, and L. Arnaud, "Acoustical properties of materials made of vegetable particles with several scales of porosity," Appl. Acoust., vol. 72, no. 5, pp. 249-259, Apr. 2011.

[35] J. Allard and N. Atalla, Propagation of Sound in Porous Media: Modelling Sound Absorbing Materials 2e, 1 edition. Hoboken, N.J: Wiley, 2009.

[36] L. Arnaud and E. Gourlay, "Experimental study of parameters influencing mechanical properties of hemp concretes," Constr. Build. Mater., vol. 28, no. 1, pp. 50-56, Mar. 2012.

[37] P. Glé, E. Gourdon, and L. Arnaud, "Modelling of the acoustical properties of hemp particles," Constr. Build. Mater., vol. 37, pp. 801-811, Dec. 2012. 
[38] V. Cerezo, Propriétés mécaniques, thermiques et acoustiques d'un matériau à base de particules végétales: approche éxpérimentale et modélisation théorique. Ecole doctorale MEGA, Lyon, 2005.

[39] P. Glé, E. Gourdon, L. Arnaud, K.-V. Horoshenkov, and A. Khan, "The effect of particle shape and size distribution on the acoustical properties of mixtures of hemp particles," J. Acoust. Soc. Am., vol. 134, no. 6, pp. 4698-4709, Dec. 2013.

[40] C. F. F. Pinto DaSilva, D. Maskell, R. J. Ball, and M. P. Ansell, "The physical, chemical and mechanical properties of eco-materials for passive indoor environmental control," in Proceedings of Advanced Building Skins, Bressanone, 2014, pp. 377-390.

[41] J. Grimes, O. Kinnane, R. Walker, and S. Pavia, "In situ measurement of the sound absorption characteristics of existing building fabrics," in Proceedings of the Institute of Acoustics, Manchester, UK, 2013, vol. 35(2).

[42] P. Glé, E. Gourdon, and L. Arnaud, "Acoustical Properties of Hemp Concretes," in Bio-aggregate-based Building Materials, S. Amziane, L. Arnaud, and N. Challamel, Eds. John Wiley \& Sons, Inc., 2013, pp. 243-266.

[43] ISO 10534-2:1998 - Acoustics -- Determination of sound absorption coefficient and impedance in impedance tubes -- Part 2: Transfer-function method. 1998.

[44] ISO 13472-2:2010 - Acoustics -- Measurement of sound absorption properties of road surfaces in situ -- Part 2: Spot method for reflective surfaces. 2010.

[45] S. V. Joshi, L. T. Drzal, A. K. Mohanty, and S. Arora, "Are natural fiber composites environmentally superior to glass fiber reinforced composites?," Compos. Part Appl. Sci. Manuf., vol. 35, no. 3, pp. 371-376, Mar. 2004.

[46] A. Evrard, Bétons de chanvre: synthèse des propriétés physiques. Association Construire en Chanvre, 2003.

[47] A. Kashtanjeva, M. Sonebi, and S. Amziane, "Investigation of the Mechanical Performance and Drying Shrinkage of Hemp Concrete," in Proceedings of the First International Conference on Bio-Based Building Materials, ClermontFerrand, France, vol. 1, pp. 309-315.

[48] S. Amziane, C. Niyigena, A. Chateauneuf, L. Arnaud, B. Laetitia, and F. Collet, "Statistical analysis of hemp concrete mechanical properties variability," in Proceedings of the First International Conference on Bio-Based Building Materials, Clermont-Ferrand, France, 2015, vol. 1, pp. 334-341.

[49] E. Gourley, P. Gle, C. Foy, S. Marceau, and S. Moscardelli, "Impact of the water content of hemp concretes on their thermal and acoustical properties," in Proceedings of the First International Conference on Bio-Based Building Materials, Clermont-Ferrand, France, vol. 1, pp. 430-436.

[50] EN 459-1:2010 - Building lime. Definitions, specifications and conformity criteria. Brussels: European Committee for Standardisation CEN, 2010.

[51] EN 197-1:2011 Cement. Composition, specifications and conformity criteria for common cements. Brussels: European Committee for Standardisation CEN, 2011.

[52] R. Walker, A Study of the Properties of Lime-Hemp Concrete with Pozzolans'. Dublin, Ireland, 2013. 
[53] R. Walker and S. Pavia, "Impact of water retainers in the strength, drying and setting of lime hemp concrete," in Bridge and Concrete Research in Ireland, Dublin, 2012.

[54] O. Kinnane, J. Grimes, J. McGinn, P. O'Shea, and S. Pavia, "Investigation of thermal resistance and bridging in examples of contemporary and vernacular solid wall architecture," presented at the Passive Low Energy Architecture Conference, Ahmedabad, India, 2014.

[55] R. Oldfield and F. Bechwati, "Accurate low frequency impedance tube measurements," in Proceedings of the Institute of Acoustics, 2008, vol. 30 (4).

[56] F. Asdrubali, S. Schiavoni, and K. Horoshenkov, "A Review of Sustainable Materials for Acoustic Applications," Build. Acoust., vol. 19, no. 4, pp. 283-312, Dec. 2012.

[57] BS EN ISO 11654:1997 Acoustics. Sound absorbers for use in buildings. Rating of sound absorption. Brussels: European Committee for Standardisation CEN, 2005.

[58] U. Berardi and G. lannace, "Acoustic characterization of natural fibers for sound absorption applications," Build. Environ., vol. 94, Part 2, pp. 840-852, Dec. 2015. 